\title{
KENDALA PENERAPAN PEMBELAJARAN TEMATIK DI KELAS RENDAH SEKOLAH DASAR
}

\author{
Sukiniarti \\ e-mail: kuniarti@ut.ac.id \\ Universitas Terbuka
}

\begin{abstract}
Abstrak: Penerapan pembelajaran tematik pada Kurikulum Tingkat Satuan Pendidikan (KTSP) diterapkan di Sekolah Dasar kelas rendah (kelas I, 2, dan 3). Namun pada Kurikulum 2013 pembelajaran tematik diterapkan di setiap jenjang tingkatan kelas mulai dari kelas 1 SD hingga kelas 6 SD, bahkan sampai jenjang sekolah menengah. Tujuan penelitian ini untuk mendeskripsikan kendala yang dihadapi guru SD kelas rendah dalam mengembangkan RPP, memilih media, dan metode pembelajaran tematik yang tepat, serta pada saat menerapkan pembelajaran tematik di kelas rendah. Penelitian yang merupakan penelitian kualitatif ini dilaksanakan April sampai dengan Juli 2012. Subjek penelitian ini adalah guru kelas rendah di SD Negeri Pulau Bangka di Provinsi Bangka Belitung. Pengumpulan data dilakukan melalui kuesioner, wawancara, observasi dan kajian dokumentasi atas RPP yang dibuat oleh guru. Hasil penelitian menunjukkan bahwa kendala yang dialami meliputi: (1) sebagian besar guru menganggap lebih sulit mengembangkan RPP tematik dibanding dengan RPP bidang studi terutama dalam menentukan metode, dan dalam menyusun soal evaluasi; (2) seluruh guru menganggap sulit menentukan media dari setiap tema yang telah ditentukan; (3) sebagian besar guru untuk menentukan tema dengan metode yang tepat, masih harus mendiskusikannya dengan sesama teman guru. Dari penelitian ini dapat disimpulkan bahwa penerapan pembelajaran tematik di SD kelas rendah akan mengalami kendala apabila guru tidak bersikap kreatif, dan apabila tidak memiliki pemahaman yang luas tentang tema yang dipilih dalam kaitannya dengan mata pelajaran yang dipadukan.
\end{abstract}

Kata kunci: kendala, penerapan pembelajaran tematik, kelas rendah.

\section{CONSTRAINTS ON THE IMPLEMENTATION OF THE THEMATIC LEARNING AT THE LOWER GRADES OF PRIMARY SCHOOL}

\begin{abstract}
Based on the curriculum of the unit level of education or school-based curriculum (KTSP), the thematic learning is designed to be implemented at the lower grades of primary school, namely grade 1, 2, and 3. However, in the Curriculum of 2013 the thematic learning is designed to be applied at all grades from 1st grade to the 6th grade, and even at the higher school levels. The purpose of this study was to describe the constraints faced by the lower grade elementary school teachers in developing the lesson plans, selecting the media, and deciding on the use of the appropriate thematic learning methods. Moreover, this study was to describe the constraints in implementing the thematic learning in the lower grade classrooms. The subjects of this qualitative research were lower grade teachers of elementary school in Bangka Belitung province. The data were collected through questionnaires, interviews, observation, and review of lesson plan documents formulated by the teachers. The results showed, the constraints experienced by the teachers included the difficulty in developing the thematic lesson plan, determining the method, selecting the media, and preparing the evaluation tools. From this study it can be concluded that the application of the thematic learning in lower grades will experience problems if the teachers are not creative and do not have a broad understanding of the selected theme in relation to the subjects combined.
\end{abstract}

Keywords: constraints, the application of thematic learning, the lower grades.

\section{PENDAHULUAN}

Perjalanan pendidikan di Indonesia, hingga saat ini belum bisa mengatasi sejumlah persoalan makro dan mikro yang melingkupinya. Beberapa permasalahan besar yang belum mampu untuk diatasi diantaranya adalah persoalan yang menyangkut guru, kurikulum, sarana dan prasarana pendidikan. Persoalan yang berkenaan dengan faktor guru mencakup segi kualitas maupun kuantitas. Pendidikan di Indonesia telah mengalami perubahan kurikulum secara berulangkali hingga tahun 2004 yang terkenal dengan Kurikulum Berbasis Kompetensi (KBK), berikutnya pada tahun 2006 yang disebut dengan Kurikulum Tingkat Satuan Pendidikan (KTSP). Dengan dikeluarkannya kebijakan tentang otonomi daerah yang telah memberikan kebebasan ruang gerak yang luas kepada lembaga pendidikan khususnya sekolah dasar dalam mengelola 
sumber daya yang ada, dengan cara mengalokasikan seluruh potensi dan prioritas sehingga mampu melakukan terobosan-terobosan sistem pembelajaran yang lebih inovatif dan kreatif, salah satunya adalah upaya kreatif dalam melaksanakan pembelajaran di sekolah dasar khususnya pada kelas rendah yaitu dengan melakukan pembelajaran tematik.

Pembelajaran model ini akan lebih menarik dan bermakna bagi anak karena model pembelajaran tematik menyajikan tema-tema pembelajaran yang lebih aktual dan kontekstual dalam kehidupan seharihari. Namun demikian masih banyak pihak yang belum memahami dan mampu menerapkan model ini secara baik.

Pembelajaran tematik merupakan pembelajaran bermakna bagi siswa, dan lebih menekankan pada penerapan konsep belajar secara utuh tidak terpisahpisah. Oleh karena itu, guru harus merancang pengalaman belajar yang akan mempengaruhi kebermaknaan belajar siswa dan menunjukkan adanya kaitan unsur-unsur konseptual yang menjadikan proses pembelajaran lebih efektif. Kaitan konseptual antar mata pelajaran yang dipelajari akan membentuk skema, sehingga siswa memperoleh keutuhan dan kebulatan pengetahuan. Penerapan pembelajaran tematik di sekolah dasar akan sangat membantu siswa, hal ini dapat dilihat dari tahap perkembangan siswa yang masih melihat segala sesuatu sebagai satu keutuhan.

Pembelajaran tematik adalah pembelajaran terpadu yang menggunakan tema untuk mengaitkan beberapa mata pelajaran sehingga dapat memberikan pengalaman yang bermakna serta memberikan keuntungan bagi siswa, diantaranya: (a) mudah memusatkan perhatian pada suatu tema tertentu; (b) mampu mempelajari pengetahuan dan mengembangkan berbagai kompetensi dasar antar mata pelajaran dalam tema yang sama; (c) pemahaman terhadap materi pelajaran lebih mendalam dan berkesan; (d) kompetensi dasar dapat dikembangkan lebih baik dengan mengaitkan mata pelajaran lain dengan pengalaman pribadi siswa; (e) lebih merasakan manfaat dari belajar karena materi disajikan dalam konteks tema yang jelas; (f) lebih bergairah belajar karena dapat berkomunikasi dalam situasi nyata, untuk memgembangkan suatu kemampuan dalam satu mata pelajaran sekaligus mempelajari mata pelajaran lain; (g) dapat menghemat waktu karena mata pelajaran yang disajikan dapat dipersiapkan sekaligus diberikan dalam dua atau tiga kali pertemuan, sedangkan selebihnya dapat digunakan untuk kegiatan remedial dan pengayaan.
Panduan pembelajaran tematik dalam KTSP dari Depdiknas 2006 mengungkapkan bahwa pembelajaran tematik merupakan satu usaha untuk mengintegrasikan pengetahuan, keterampilan, nilai, atau sikap pembelajaran, serta pemikiran yang kreatif dengan menggunakan tema. Dari pernyataan tersebut dapat ditegaskan bahwa pembelajaran tematik dilakukan dengan maksud sebagai upaya untuk memperbaiki dan meningkatkan kualitas pendidikan, terutama untuk mengimbangi padatnya materi kurikulum. Disamping itu pembelajaran tematik akan memberi peluang pembelajaran terpadu yang lebih menekankan pada partisipasi/keterlibatan siswa dalam belajar. Keterpaduan dalam pembelajaran ini dapat dilihat dari aspek proses atau waktu, aspek kurikulum, dan aspek belajar mengajar.

Sejak diberlakukannya kurikulum Tingkat Satuan Pendidikan (KTSP), Diknas Pendidikan menghimbau kelas 1 sampai kelas 3 SD untuk menerapkan pembelajaran tematik. Alasan pemerintah untuk menerapkan pembelajaran tematik antara lain: (1) pola pikiran anak masih holistik artinya usia siswa sekitar 7 - 10 tahun pola pemikirannya masih satu kesatuan, (2) usia siswa SD masih bersifat operasional kongkrit. Menurut Jean Piaget bahwa pada usia tersebut masih butuh alat peraga (media) yang kongkrit (nyata) untuk menjelaskan suatu konsep; (3) saat proses belajar untuk mengenal suatu konsep tentu tidak lepas dari kehidupan yang paling dekat dengan lingkungan siswa, oleh karenanya melalui payung tema yang sesuai dengan tahapan perkembangan anak, pembelajaran menjadi lebih bermakna, sehingga kegiatan pembelajaran bagi anak kelas awal SD sebaiknya dilakukan dengan pembelajaran tematik. Namun dalam pelaksanaannya masih banyak kendala yang dialami guru sehingga guru enggan menerapkan pembelajaran dengan pendekatan tematik. Hal ini terjadi hampir di seluruh sekolah dasar di Indonesia. Mereka membuat RPP mengikuti standar kompetensi pembelajaran tematik, tapi pelaksanaan pembelajaran masih terpisah-pisah, misalnya pertemuan pertama membahas IPA, pertemuan kedua membahas matematika, pertemuan ketiga membahas IPS, begitu seterusnya. Hal seperti ini sama dengan informasi yang diterima penulis dari guru-guru SD yang masih berpendidikan D2 PGSD dan sedang melanjutkan ke S1 PGSD.

Indah Lestari (2012) dalam artikelnya dikatakan bahwa kendala penerapan pembelajaran tematik yang dialami oleh guru dikarenakan guru belum memahami dengan baik tentang pembelajaran tematik, sehingga kemampuan untuk menerapkan model pembelajaran 
tematik terbatas.

Berdasarkan uraian tersebut di atas penulis tertarik melakukan penelitian tentang penerapan pembelajaran tematik yang nampaknya masih banyak tantangan yang harus dihadapi. Tepatnya di Sekolah Dasar Pulau Bangka Kepulauan Bangka Belitung. Oleh karenanya penulis ingin mengajukan permasalahan sebagai berikut.

Kendala apakah yang dihadapi guru SD kelas rendah, pada saat: (1) mengembangkan RPP tematik? ; (2) cara memilih media yang tepat dengan tema yang dipilih dalam pembelajaran tematik?; (3) memilih tema dalam pembelajaran tematik?; dan (4) menerapkan pembelajaran tematik di kelas rendah?

Tujuan penelitian ini untuk mendeskripsikan kendala yang dihadapi guru SD kelas rendah, pada saat mengembangkan RPP tematik, cara memilih media yang tepat dengan tema yang dipilih dalam pembelajaran tematik, memilih tema dalam pembelajaran tematik, dan pada saat menerapkan pembelajaran tematik di SD kelas rendah Pulau Bangka.

Manfaat yang diharapkan dari penelitian ini adalah: (1) semua guru SD yang mengajar di kelas rendah (kelas 1, 2, dan 3) Khususnya di Pulau Bangka dapat meningkatkan kemampuan mereka dalam membelajarkan tematik; (2) semua guru SD agar selalu berupaya untuk memperbaiki cara mengajar mereka serta diharapkan para guru memiliki kemampuan dalam menggambungkan sejumlah konsep dalam beberapa mata pelajaran yang berbeda; (3) melalui penerapan pembelajaran tematik, sekolah diharapkan berusaha mempersiapkan berbagai sarana seperti media, buku-buku pelajaran, serta sarana lain yang menunjang pembelajaran tematik; (4) menyiapkan guru-guru mereka untuk mengikuti pelatihan maupun penataran tentang penerapan pembelajaran tematik di sekolah; (5) para siswa SD kelas rendah dengan adanya pendekatan tematik, pembelajaran menjadi menarik dan menyenangkan sehingga mereka menjadi lebih mudah dalam memahami materi yang diajarkan guru.

\section{Kajian Pustaka}

Pembelajaan tematik adalah pembelajaran tepadu yang menggunakan tema untuk mengaitkan beberapa mata pelajaran sehingga dapat memberikan pengalaman bermakna kepada siswa. Robin Fogarty (1991) mengemukaakn bahwa ada sepuluh model pembelajaran terpadu, yakni: (1) model Fragmented, (2) connected, (3) nested, (4) sequenced, (5) shared, (6) webbed, (7) threaded, (8) integrated, (9) immersed, (10) networked. Pandangan lain yaitu Hernawan (2007: 1.26) mengungkapkan berdasarkan hasil pengkajian
Tim Pengembang PGSD (1997), terdapat tiga (3) model pembelajaran terpadu yang paling relevan diterapkan di sekolah dasar, yaitu model jaring laba-laba (webbing), model keterhubungan (connected), model keterpaduan (integrated). Hernawan (2009:1.5) mengungkapkan bahwa pembelajaran tematik adalah pembelajaran yang beranjak dari suatu tema tertentu sebagai pusat perhatian (center of interest) yang digunakan untuk memahami gejala-gejala dan konsep lain, baik yang berasal dari mata pelajaran yang bersangkutan maupun dari mata pelajaran lainnya. Drake \& Burns (2004:8) membedakan tiga pendekatan kurikulum terpadu yaitu multidisciplinary, interdisciplinary, dan transdisciplinary. Pendekatan multimatapelajaran terutama fokus pada mata pelajaran.

Penggunaan pendekatan ini dilakukan dengan mengorganisasi standar dari matapelajaran di sekitar sebuah tema. Pendekatan Antar-matapelajaran (interdisciplinary), adalah bentuk pembelajaran yang yang menggambungkan sebuah mata pelajaran dalam sebuah tema. Kegiatan pembelajaran berlangsung dalam waktu yang bersamaan. Pendekatan transdisiplinari dilakukan dengan membangun kurikulum di sekitar pertanyaan dan perhatian siswa. Siswa mengembangkan kecakapan hidup seperti yang diterapkan pada interdisiplinari dan ketrampilan mata pelajaran dalam konteks kehidupan nyata.

Hal ini dapat diartikan bahwa tujuannya adalah agar efisien waktu serta menghilangkan materi yang tumpang tindih. Namun dari hasil pengkajian Tim Pengembang PGSD (1997) dalam Asep Hery Hernawan, Novi Resmini, dan Andayani 2013: 1.26, terdapat tiga model pembelajaran terpadu yang paling tepat diterapkan di sekolah dasar di Indonesia, yakni: model jaring laba-laba (webbing), model keterhubungan (connected), dan model keterpaduan (intergrated),

Pembelajaran tematik itu sendiri disebut juga pembelajaran terpadu adalah suatu pendekatan pembelajaran yang melibatkan beberapa mata pelajaran untuk memberikan pengalaman yang bermakna kepada siswa. Bermakna dalam arti, siswa akan memahami konsep-konsep yang mereka pelajari melalui pengalaman langsung dan mengkaitkannya dengan konsep lain yang sudah mereka pahami.

Kurikulum 2013 dicanangkan semua jenjang pendidikan dalam penerapan pembelajarannya berpedoman menurut pola pembelajaran tematik yang beranjak dari sebuah tema. Jumlah tema yang dikutip dari kurikulum 2013 untuk kelas 1, 2, dan 3 ada 25 tema, yang meliputi hal-hal sebagai berikut.

Kelas 1: (1) diri sendiri, (2) kegemaranku, (3) 
kegiatanku, (4) keluargaku, (5) pengalamanku, (6) lingkungan bersih, sehat, dan Asri, (7) benda, binatang, dan tanaman disekitarku, (8) peristiwa alam. Kelas 2: (1). Hidup rukun, (2) bermain dilingkunganku, (3) tugasku sehari-hari, (4) aku dan sekolahku, (5) hidup bersih dan sehat, (6) air, bumi, dan matahari, (7) merawat hewan dan tumbuhan, (8) keselamatan di rumah dan perjalanan. Kelas 3: (1) sayangi hewan, tumbuhan disekitar, (2) pengalaman yang mengesankan, (3) mengenal cuaca dan musim, (4) ringan sama dijinjing, berat sama dipikul, (5) mari kita bermain dan berolahraga, (6) indahnya persahabatan, (7) mari kita hemat energi untuk masa depan, (8) berperilaku baik dalam kehidupan sehari-hari.

Trianto (2010), menyatakan bahwa pembelajaran tematik apabila ditinjau dari aspek guru dan siswa memiliki beberapa keuntungan antara lain: (1) materi pelajaran tidak dibatasi oleh jam pelajaran , da mencakup berbagai mata pelajaran; (2) guru dapat membantu siswa memperluas memperluas kesempatan belajar ke berbagai aspek kehidupan; (3) guru bebas membantu siswa melihat suatu masalah atau topik dari berbagai sudut pandang; (4) penekanan pada kompetensi bisa dikurangi dan diganti dengan kerjasama dan kolaborasi. Pembelajaran Tematik sangat tepat diajarkan pada siswa Sekolah Dasar kelas rendah, yaitu kelas I, II, dan III karena siswa kelas 1 hingga kelas III pada umumnya masih berusia 7 hingga 9 tahun. Anak usia tersebut menurut teori Piaget masih dalam periode operasi konkrit. Periode operasional konkrit menurut Piaget berawal pada anak usia 6 atau 7 tahun dan berakhit pada usia 11 tahun. Usia -usia ini merupakan usia di mana anak belajar di sekolah dasar, di mana cara berpikir mereka belum terpisah-pisah. Pada umumnya mereka masih melihat segala sesuatu sebagai satu keutuhan (Holistik ). Sumantri M (2007) mengungkapkan, pendidikan pada anak usia SD sebaiknya guru perlu mengetahui benar sifat-sifat serta karakteristik anak usia SD agar dapat memberikan pembinaan dengan baik dan tepat sehingga dapat meningkatkan potensi kecerdasan dan kemapuan anak didik sesuai kebutuhan anak dan harapan orang tua khususnya dan harapan masyarakat pada umumnya.

Widodo Rahmad (2009) menyatakan bahwa anak yang berada pada rentangan kelas rendah, perkembangan fisiknya tidak bisa dipisahkan dengan perkembangan mental, sosial dan emosional, sehinggap Pembelajaran Tematiklah yang paling tepat untuk membelajarkan mereka. Tidak semua anak yang masuk kesekolah dasar berasal dari pendidikan taman kanak-kanak, melainkan hanya dididik sendiri oleh orang tuanya, tentunya pengetahuan dan pengalaman belajarnya akan berbeda. Oleh karena itu, maka perlu disatukan minimal pengertian- pengertian mendasar yang diperlukan siswa untuk jenjang pendidikan selanjutnya. Maka dari itu untuk seorang guru dalam mengajar dengan menerapkan pendekatan tematik harus mempunyai keterampilan khusus mulai dari menentukan tema dan sarana dan prasarana yang dipergunakannya, termasuk model pembelajaran tematik. Penerapan pembelajaran tidak semulus yang diharapkan pemerintah. Dalam penerapannya masih banyak kendala dari berbagai pihak.

Kendala menurut kamus besar bahasa Indonesia edisi keempat adalah rintangan atau keadaan yang membatasi. Kendala penerapan pembelajaran tematik berarti keadaan yang membatasi guru-guru dalam menerapkan pembelajaran tematik, misalnya komponen-komponen yang berkaitan dalam menerapkan pembelajaran tematik mulai dari menetapkan model pembelajaran tematik, menetukan tujuan pembelajaran, menentukan indikator, menentukan metode yang relevan, menentukan langkah-langkah dalam kegiatan belajar mengajar, menyusun rencana pelaksanaan pembelajaran $(\mathrm{RPP})$, serta menentukan media pembelajaran yang menunjang pembelajaran tematik.

Hasil penelitian terdahulu yang dilakukan oleh Hernawan A H, Novi R, (2009: 1.5), kendala dalam penerapan pembelajaran tematik adalah: (1) tidak semua kompetensi dasar dalam KTSP dapat dipadukan; (2) kalau tidak ditunjang sarana dan prasarana yang diperlukan dalam pelaksanaan pembelajaran tematik, proses pembelajaran tidak berjalan dengan baik sehingga dapat berpengaruh pada hasil belajar siswa; (3) belum semua guru sekolah dasar memahami konsep pembelajaran tematik secara utuh. Guru merasa senang dengan proses pembelajaran yang sudah biasa dilakukan yaitu bukan pendekatan tematik. Kendala lain yang ditemui oleh Karli (2012) adalah: (1) perencanaan pembelajaran tematik yang memakan waktu dan tenaga yang lebih banyak mulai dari penyusunan matriks tematik, jaring laba-laba, program semester, silabus dan RPP sekaligus dibuat dalam 1 semester; (2) tidak berurutan materi yang diajarkan kecuali matematika dalam 1 semester; dan (3) menyiapkan media perlu disesuaikan dengan pemilihan tema. Kendala penerapan pembelajaran tematik yang diperoleh dari Sukandar yaitu: pertama masih terjadi selisih pendapat para Guru tentang pengertian, maksud dan tujuan Pembelajaran Tematik, kedua: terjadi kebingungan dan merasa repot dan berat para guru untuk menerapkan Pembelajaran 
Tematik.

Hasil penelitian yang dilakukan oleh Nurul (2012) dalam pelaksanaan model pembelajaran tematik di SD Negeri 01 Sirau adalah: (1) keterbatasan sarana dan prasarana sekolah; (2) latar belakang pendidikan guru masih rendah; (3) keterbatasan pengetahuan guru mengenai penerapan model pembelajaran tematik; (4) keterbatasan penggunaan model dan media pembelajaran; (5) sulitnya mengubah cara mengajar guru. Permasalahan lain yang muncul dari hasil penelitian yang dilakukan oleh Pujiastuti (2011) yaitu: (1) guru kesulitan dalam melakukan penilaian bagi siswa kelas 1 yang belum lancar membaca dan menulis; (2) penilaian lisan, unjuk kerja, tingkah laku, produk maupun portofolio sudah dilakukan namun jarang didokumentasikan; (3) guru masih kesulitan membuat instrumen penilaian unjuk kerja, produk dan tingkah laku, sehingga cenderung lebih suka menggunakan penilaian tertulis; (4) guru masih kesulitan menentukan Kriteria ketuntansan Minimal; (5) guru juga menemui kesulitan dalam cara menilai pembelajaran tematik, karena rapor siswa menggunakan mata pelajaran. Penelitian lain dilakukan oleh Imron Rosadi (2009), hasil penelitiannya tentang studi kasus pelaksanaan pembelajaran tematik di kelas II SDN Mergosono I Kota Malang adalah: (1) Kelas II SDN Mergosono I Kota Malang telah melaksanakan persiapan pelaksanaan pembelajaran tematik akan tetapi dalam hal penyusunan RPP Tematik, mereka masih mengalami kesulitan; (2) Pelaksanaan pembelajaran tematik di kelas II SDN Mergosono I Kota Malang masih belum melaksanakan pembelajaran tematik secara optimal; (3) Hasil belajar melalui pembelajaran tematik di kelas II SDN Mergosono I Kota Malang, guru masih menilai peserta didik berdasarkan per mata pelajaran; (4) Penerapan pembelajaran tematik di kelas II SDN Mergosono I Kota Malang masih ada hambatan dikarenakan kurikulum tidak dikemas dalam bentuk tematik; (5) Kepala sekolah dan Penilik/ Pengawas sekolah lebih mengambil kebijakan untuk pencapaian hasil belajar akhir program yang masih bersifat terpisah-pisah tiap mata pelajaran sehingga kurang memberikan perhatian pada pengembangan pembelajaran tematik.

Samsuri. (2013) mengatakan bahwa kenyataannya masih banyak dijumpai bahwa sebagian besar guru- guru yang mengajar di kelas rendah SD belum akrab dengan pendekatan pembelajaran tematik terpadu di kelasnya masing-masing. Berdasarkan uraian tersebut di atas, dinyatakan bahwa dalam penerapan pembelajaran tematik di SD kelas rendah masih banyak kendala yang dialami oleh guru.

\section{METODE PENELITIAN}

Penelitian ini menggunakan metode deskriptif kualitatif. Penelitian ini dilaksanakan dari bulan April sampai dengan Juli 2012. Pengumpulan data dalam penelitian ini menggunakan angket, observasi, wawancara, dan dokumentasi. Populasi dalam penelitian ini adalah guru SD di Provinsi Bangka Belitung. Sementara sebagai sampel adalah guru SD di wilayah Pulau Bangka. Pengambilan sampel penelitian penulis berkolaborasi dengan teman yang bertugas di Pulau Bangka Belitung. Pengambilan sampel dilakukan dengan teknik proposional random sampling sebanyak $10 \%$ dari populasi penelitian. Pengumpulan data dilakukan melalui pengisian kuesioner. Berdasarkan data yang diperoleh dari kuesioner, dilakukan tindak lanjut melalui wawancara langsung dengan para guru ditempat mereka mengajar, serta melakukan observasi, dan studi dokumentasi terhadap RPP yang telah disusun oleh guru.

Data yang terkumpul dari hasil kuesioner kemudian dianalisis secara deskriptif kuantitatif. Metode diskriptif menurut Travers (dalam Svilla et,al.2006) adalah metode yang digunakan untuk menggambarkan suatu keadaan yang sementara berjalan pada saat penelitian dilakukan.Untuk memudahkan menganalisis data, data dihitung secara prosentasi.

\section{HASIL DAN PEMBAHASAN}

Hasil penelitian yang meliputi kendala saat mengembangkan: (1) RPP tematik; (2) cara memilih media yang tepat dengan tema yang dipilih dalam pembelajaran tematik; (3) cara memilih tema dalam pembelajaran tematik; dan (4) menerapkan pembelajaran tematik di kelas rendah. Hasil penelitian tercantum pada tabel 1 .

Tabel 1. Kendala Dalam Menyusun Komponenkomponen RPP Tematik

\begin{tabular}{|c|l|c|c|c|c|c|c|}
\hline \multirow{2}{*}{ No } & \multicolumn{1}{|c|}{ Pernyataan } & \multicolumn{5}{|c|}{ Jumlah Mahasiswa } & JmI \\
\cline { 3 - 6 } & SS & S & KS & TS & STS & J \\
\hline & $\begin{array}{l}\text { Keterbatasan pengetahuan } \\
\text { guru mengenai penera- } \\
\text { pan model pembelajaran } \\
\text { tematik, merupakan } \\
\text { salah satu kendala dalam } \\
\text { menerapkan pembelaja- } \\
\text { ran tematik di SD kelas } \\
\text { rendah. }\end{array}$ & 0 & 54 & 45 & 0 & 0 & 99 \\
\hline 2 & $\begin{array}{l}\text { Menentukan jenjang } \\
\text { kemampuan dalam } \\
\text { menyusun soal evaluasi, } \\
\text { merupakan kendala dalam } \\
\text { mengembangkan RPP } \\
\text { tematik }\end{array}$ & 2 & 65 & 30 & 3 & 0 & 100 \\
\hline
\end{tabular}




\begin{tabular}{|c|l|c|c|c|c|c|c|}
\hline 3 & $\begin{array}{l}\text { Untuk mengatasi kendala } \\
\text { dalam menyusun RPP } \\
\text { tematik, membuatnya } \\
\text { secara bersama-sama pada } \\
\text { gugus }\end{array}$ & 0 & 80 & 20 & 0 & 0 & 100 \\
\hline Jml & 2 & 199 & 95 & 3 & 0 & \\
\hline
\end{tabular}

Keterangan: SS (Sangat Setuju), S (Setuju), KS (Kurang Setuju, TS (Tidak Setuju), STS (Sangat Tidak Setuju),

Berdasarkan tabel 1, menunjukkan bahwa sebagian besar guru setuju bahwa kendala dalam menerapkan pembelajaran tematik di SD kelas rendah dikarenakan keterbatasan pengetahuan guru mengenai penerapan model pembelajaran tematik. Selain itu juga mengalami kendala dalam menentukan jenjang kemampuan dalam menyusun soal evaluasi dalam mengembangkan RPP tematik. Berikutnya juga sebagian besar guru setuju bahwa untuk mengatasi kendala tersebut menyusun RPP tematik dilakukan secara bersama-sama pada gugus.

Hasil penelitian ini senada dengan kendala yang diperoleh dari hasil penelitian yang dilakukan oleh Nurul (2012) dalam pelaksanaan model pembelajaran tematik di SD Negeri 01 Sirau yaitu: (1) keterbatasan sarana dan prasarana sekolah, (2) latar belakang pendidikan guru masih rendah, (3) keterbatasan pengetahuan guru mengenai penerapan model pembelajaran tematik, (4) keterbatasan penggunaan model dan media pembelajaran, (5) sulitnya mengubah cara mengajar guru. Kendala Guru dalam Memilih Media yang Tepat dengan Tema yang Dipilih dalam Pembelajaran Tematik tertera pada tabel 2.

Tabel 2. Kendala Memilih Media yang Tepat dengan Tema yang Dipilih dalam Pembelajaran Tematik

\begin{tabular}{|c|c|c|c|c|c|c|c|}
\hline \multirow{2}{*}{ No } & \multirow{2}{*}{ Pernyataan } & \multicolumn{5}{|c|}{ Jumlah Mahasiswa } & \multirow{2}{*}{ Jml } \\
\hline & & SS & $\mathbf{S}$ & KS & TS & STS & \\
\hline 1 & $\begin{array}{l}\text { Dalam mengembangkan } \\
\text { materi tematik, seringkali } \\
\text { terkendala dengan media } \\
\text { pembelajaran yang kami } \\
\text { miliki }\end{array}$ & 0 & 50 & 50 & 0 & 0 & 100 \\
\hline 2 & $\begin{array}{l}\text { Mengaitkan tema dengan } \\
\text { jenis mata pelajaran yang } \\
\text { dipadukan mengalami ke- } \\
\text { sulitan menentukan media } \\
\text { yang tepat }\end{array}$ & 0 & 80 & 0 & 0 & 0 & 80 \\
\hline 3 & $\begin{array}{l}\text { Tidak semua tema dapat } \\
\text { ditentukan medianya yang } \\
\text { paling sesuai }\end{array}$ & 0 & 80 & 0 & 0 & 0 & 80 \\
\hline & $\mathrm{Jml}$ & 0 & 210 & 50 & 0 & 0 & \\
\hline
\end{tabular}

Keterangan: SS (Sangat Setuju), S (Setuju), KS (Kurang Setuju, TS (Tidak Setuju), STS (Sangat Tidak Setuju),

Berdasarkan tabel 2, menunjukkan bahwa sebagian besar guru setuju mengatakan bahwa mengaitkan tema dengan jenis mata pelajaran yang dipadukan mengalami kesulitan menentukan media yang tepat.

Hasil penelitian ini senada dengan pendapat Sutiyono (2012) bahwa pembelajaran tematik ini akan dapat diterapkan dan dilaksanakan dengan baik apabila didukung dengan berbagai sumber belajar yang dibutuhkan dalam pembelajaran, sehingga guru ketika menyelenggarakan pembelajaran tematik akan dengan mudah memanfaatkan sumber belajar yang ada, baik dengan cara membawa sumber belajar ke dalam kelas maupun mengajak siswa ke lingkungan sekitar yang terpisah dari ruang. Kendala dalam memilih tema dalam pembelajaran tematik tertera pada tabel 3 .

Tabel 3. Kendala Memilih Tema pada Pembelajaran Tematik

\begin{tabular}{|c|c|c|c|c|c|c|c|}
\hline \multirow{2}{*}{ No } & \multirow{2}{*}{ Pernyataan } & \multicolumn{5}{|c|}{ Jumlah Mahasiswa } & \multirow{2}{*}{ Jml } \\
\hline & & SS & $\mathbf{S}$ & KS & TS & STS & \\
\hline 1 & $\begin{array}{l}\text { Menentukan tema yang } \\
\text { tepat dalam pembelaja- } \\
\text { ran tematik merupakan } \\
\text { salah satu kendala dalam } \\
\text { menerapkan pembelajaran } \\
\text { tematik }\end{array}$ & 11 & 89 & 20 & 0 & 0 & 120 \\
\hline 2 & $\begin{array}{l}\text { Sebuah tema tidak dapat } \\
\text { memotivasi siswa dalam } \\
\text { belajar apabila metode } \\
\text { mengajar yang digunakan } \\
\text { guru kurang tepat }\end{array}$ & 20 & 80 & 0 & 0 & 0 & 100 \\
\hline 3 & $\begin{array}{l}\text { Untuk menentukan tema } \\
\text { dengan metode yang tepat } \\
\text { dengan mata pelajaran } \\
\text { yang dipadukan masih } \\
\text { sulit dalam penerapannya }\end{array}$ & 11 & 80 & 0 & 0 & 0 & 91 \\
\hline 4 & $\begin{array}{l}\text { Untuk mengatasi kesulitan } \\
\text { menentukan tema dengan } \\
\text { metode yang tepat dengan } \\
\text { mata pelajaran yang } \\
\text { dipadukan mendiskusikan- } \\
\text { nya dengan sesama guru } \\
\text { di KKG }\end{array}$ & 20 & 80 & 0 & 0 & 0 & 100 \\
\hline & $\mathrm{Jml}$ & 62 & 329 & 20 & 0 & 0 & \\
\hline
\end{tabular}

Keterangan: SS (Sangat Setuju), S (Setuju), KS (Kurang Setuju, TS (Tidak Setuju), STS (Sangat Tidak Setuju),

Berdasarkan tabel 3 menunjukkan sebagian besar guru mengatakan setuju apabila kendala dalam menerapkan pembelajaran tematik dikarenakan guru masih merasa sulit untuk menentukan tema dengan metode yang tepat dengan mata pelajaran yang dipadukan, sehingga untuk mengatasinya harus mendiskusikannya dengan sesama guru di KKG.

Hasil penelitian ini senada dengan yang dialami oleh Sukini (2012) dalam jurnal yang ditulisnya bahwa banyak guru peserta PLPG yang kebingungan dalam 
menentukan tema yang sesuai dengan kompetensi dasar (KD) yang setidaknya dari tiga mata pelajaran yang ditematikkan. Akibatnya, tema yang dipilih kurang dapat digunakan untuk mengeksploitasi KD dari mata pelajaran tertentu yang ditematikkan, bahkan ada pula peserta PLPG yang terjebak pada KD tertentu yang diterima dari panitia sehingga hanya membahas KD yang diterima dan tidak dipadukan dengan mata pelajaran-mata pelajaran yang lain. Kendala dalam menerapkan pembelajaran tematik di kelas rendah tertera pada tabel 4 berikut.

Tabel 4. Kendala Menerapkan Pembelajaran Tematik di Kelas Rendah

\begin{tabular}{|c|c|c|c|c|c|c|c|}
\hline \multirow{2}{*}{ No } & \multirow{2}{*}{ Pernyataan } & \multicolumn{5}{|c|}{ Jumlah Mahasiswa } & \multirow{2}{*}{ Jml } \\
\hline & & SS & $\mathbf{S}$ & KS & TS & STS & \\
\hline 1 & $\begin{array}{l}\text { Pengalaman mengajar } \\
\text { menggunakan pendekatan } \\
\text { tematik masih minim } \\
\text { sehingga masih banyak } \\
\text { kendala dalam menerap- } \\
\text { kannya }\end{array}$ & 11 & 89 & 20 & 0 & 0 & 120 \\
\hline 2 & $\begin{array}{l}\text { Sarana dan media untuk } \\
\text { menunjang pembelajaran } \\
\text { tematik di sekolah Anda } \\
\text { masih terbatas, sehingga } \\
\text { mengalami kesulitan } \\
\text { dalam menerapkan pem- } \\
\text { belajaran }\end{array}$ & 20 & 60 & 20 & 0 & 0 & 100 \\
\hline 3 & $\begin{array}{l}\text { Menyajikan pembelajaran } \\
\text { tematik pada siswa kelas } \\
\text { rendah, lebih sulit dari } \\
\text { mengajar pada kelas tinggi }\end{array}$ & 10 & 56 & 34 & 0 & 0 & 100 \\
\hline 4 & $\begin{array}{l}\text { Mengajar di kelas } \\
\text { rendah lebih banyak } \\
\text { menghabiskan waktu } \\
\text { untuk mengelola kelas } \\
\text { (menenangkan siswa agar } \\
\text { mereka mau belajar) }\end{array}$ & 0 & 54 & 36 & 0 & 0 & 90 \\
\hline & $\mathrm{Jml}$ & 41 & 259 & 110 & 0 & 0 & \\
\hline
\end{tabular}

Keterangan: SS (Sangat Setuju), S (Setuju), KS (Kurang Setuju, TS (Tidak Setuju), STS (Sangat Tidak Setuju)

Berdasarkan tabel 4 menunjukkan bahwa sebagian besar guru setuju bahwa kendala dalam menerapkan pembelajaran tematik dikelas rendah dikarenakan pengalaman mengajar menggunakan pendekatan tematik masih minim, masih merasa sulit menyajikan pembelajaran tematik pada siswa kelas rendah, dibanding mengajar pada kelas tinggi, dan sebagian besar sarana untuk menunjang pembelajaran tematik di sekolah cenderung masih terbatas, sehingga mengalami kesulitan dalam menerapkan pembelajaran tematik.

Hasil penelitian ini sesuai dengan penelitian yang dilakukan oleh Hikmah, N. (2012) di SD Negeri 01 Sirau Karangmoncol Purbalingga, bahwa kendala dalam menerapkan pembelajaran tematik adalah: (a) keterbatasan sarana dan prasarana sekolah, (b) latar belakang pendidikan guru masih rendah, (c) keterbatasan pengetahuan guru mengenai penerapan model pembelajaran tematik, (d) keterbatasan penggunaan model dan media pembelajaran, dan (e) sulitnya mengubah cara mengajar guru.

Pendapat lain menurut Karli, Hilda (2012) mengatakan bahwa kendala Pembelajaran Tematik adalah sebagai berikut: (a) Perencanaan pembelajaran tematik yang memakan waktu dan tenaga yang lebih banyak mulai dari penyusunan matriks tematik, jaring laba-laba, program semester, silabus dan RPP sekaligus dibuat dalam 1 semester; (b) Tidak berurutan materi yang diajarkan kecuali Matematika dalam 1 semester; dan (c) Menyiapkan media perlu disesuaikan dengan pemilihan tema.

Beberapa cara mengatasi kendala Pembelajaran Tematik sebagai berikut: (a) Kerja Team Work dari para guru SD tiap jenjang untuk membuat perencanaan hingga pelaksanaan; (b) Para siswa diajak terlibat untuk menyiapkan media sesuai dengan tema, paling tidak 3 hari sebelumnya; dan (c) Menggunakan bahan ajar Tematik untuk membantu guru baik dari persiapan, pelaksanaan bahkan evaluasi.

Berdasarkan uraian tersebut di atas untuk mengurangi kendala dalam melaksanakan pembelajaran tematik di kelas rendah seyogianya sekolah harus menyediakan sarana pembelajaran sesuai dengan kebutuhan siswa, perlu adanya latihan khusus untuk menyusun RPP tematik dan dari pihak Diknas harus melakukan supervisi secara teratur kesekolah- sekolah.

Wahyuni, V (2013) menyatakan bahwa kunci keberhasilan pembelajaran tematik terletak pada kreativitas guru mengolah tema dan potensi siswa.

\section{PENUTUP}

\section{Kesimpulan}

Berdasarkan hasil temuan dalam penelitian dan pembahasan, maka penelitian ini dapat disimpulkan sebagai berikut.

Pertama, bahwa sebagian besar guru sependapat bahwa kendala dalam menerapkan pembelajaran tematik di SD kelas rendah dikarenakan keterbatasan pengetahuan guru mengenai penerapan model pembelajaran tematik. Cara mengatasinya sebagian besar guru setuju bahwa untuk mengatasi kendala tersebut menyusun RPP tematik dilakukan secara bersama-sama pada gugus. Kedua, kendala dalam menerapkan pembelajaran tematik dikarenakan keterbatasan media yang mereka miliki, sehingga kesulitan menentukan 
media yang tepat dalam mengaitkan tema dengan mata pelajaran yang dipadukan.

Ketiga, sebagian besar guru mengatakan bahwa kendala dalam menerapkan pembelajaran tematik dikarenakan guru masih merasa sulit untuk menentukan tema dengan metode yang tepat dengan mata pelajaran yang dipadukan, sehingga untuk mengatasinya harus mendiskusikannya dengan sesama guru di KKG.

Keempat, kendala dalam menerapkan pembelajaran tematik dikelas rendah dikarenakan pengalaman mengajar guru menggunakan pendekatan tematik masih minim, masih merasa sulit menyajikan pembelajaran tematik pada siswa kelas rendah, dan sebagian besar sarana untuk menunjang pembelajaran tematik di sekolah cenderung masih terbatas, sehingga mengalami kesulitan dalam menerapkan pembelajaran tematik.

\section{Saran}

Pembelajaran tematik dalam penerapannya terbukti masih mengalami banyak hambatan baik dari pihak guru maupun dari sarana dan prasarana. Maka dari itu penulis menyarankan beberapa hal sebagai berikut.

Pertama, guru harus memahami betul konsep pembelajaran tematik atau pembelajaran terpadu sehingga penerapan pembelajaran tematik sesuai dengan tuntutan kurikulum. Kedua, sarana dan prasarana yang meliputi media, alat peraga, sumber belajar harus dipenuhi atau dilengkapi di setiap jenjang pendidikian. Ketiga, perlu adanya pelatihan terhadap guru-guru cara menyusun RPP, menentukan alat peraga, maupun media yang tepat dengan tema yang telah dipilih dari mata pelajaran yang dipadukan.

Keempat, berdasarkan Permen Diknas nomor 14 Tahun 2007, guru harus mampu melakukan pergeseran paradigma proses pendidikan, yaitu dari paradigma pengajaran ke paradigma pembelajaran. Pembelajaran adalah proses interaksi peserta didik dengan guru dan sumber belajar pada suatu lingkungan belajar. Proses pembelajaran perlu direncanakan, dilaksanakan, dinilai, dan diawasi agar terlaksana secara efektif dan efisien.

\section{DAFTAR PUSTAKA}

Departemen Pendidikan Nasional. (2008). Kamus besar bahasa Indonesia pusat bahasa. Edisi Keempat. Jakarta: PT Gramedia Pustaka Utama.

Dewi, M A. (2013). “Analisis hambatan pelaksanaan model pembelajaran tematik oleh guru kelas rendah di SDN Bringin 01, 02 \& 03 kecamatan Bringin kabupaten Semarang Tahun Pelajaran
2011/2012". Journal Student UNY. Vol.II No. 1 Tahun 2013. Di akses dari http://journal. student.uny.ac.id/jurnal/artikel/1726/99/258 tanggal 9 Januari 2014

Drake, S.M. \& Burns, R. C. (2004). Meeting standars through integrated curriculum. Alexandria: Association for Supervision and Curriculum Development.

Forgarty, R. (1991). How to integrated the curricula. Palatine, Illinois: IRI/Skylight Publishing, Inc.

Hernawan, A.H, Novi R, \& Adayani. (2013). Pembelajaran terpadu di SD. Jakarta: Universitas Terbuka

Hikmah, N (2012). “Dinamika pelaksanaan model pembelajaran tematik di sekolah dasar terpencil Karangmoncol Purbalingga tahun ajaran 2011/2012". Thesis. Yogyakarta: Universitas Negeri Yogyakarta.

Hilda, K. (2012). Penerapan pembelajaran tematik $S D$ di Indonesia. Diakses tanggal 29 April 2013 dari http://hildakarliuninus.blogspot. com/2012/01/pembelajaran-tematik-di-indonesia.html

Lestari, P.I. (2012). Implementasi manajemen pembelajaran dengan pendekatan tematik dalam upaya peningkatan aktivitas dan motivasi belajar pada siswa kelas permulaan di SD Cipta Dharma Denpasar. Program Studi administrasi Pendidikan. Pasca Sarjana, Universitas Pendidikan Ganesha.

Irwandi. (2012). "Pelaksanaan model pembelajaran tematik bagi siswa tunagrahita ringan di SlB hikmah reformasi Padang". Jurnal Ilmiah Pendidikan Khusus Volume 1 Nomor 2 Tahun 2012. Diakses dari http://ejournal.unp.ac.id/index. php/jupekhu/article/viewFile/847/704 tanggal 12 Februari 2014

Pujiastuti, A. (2011). Permasalahan penerapan pembelajaran tematik di kelas awal sekolah dasar. Diakses tanggal 1 mei 2013 dari http://library.um.ac. id/free-contents/index.php/pub/detail/ permasalahan-penerapan-pembelajaran-tematik-di-kelas-awal-sekolah-dasar-ari-pudjiastuti-47508.html

Rachmad, W. (2009). Strategi pembelajaran tematik. Diakses tanggal 3 Mei 2013 dari http:/ / wyw1d. wordpress.com/2009/10/12/strategi-pembelajaran-tematik/

Samsuri. (2013). Kebijakan pembelajaran tematik terpadu Kurikulum 2013. Pengantar Kuliah Umum Program Studi Pendidikan Dasar. Penerbit: Program Pascasarjana Universitas Negeri Medan

Sukini. (2011). "Pembelajaran tematik sekolah dasar kelas rendah dan pelaksanaannya". Jurnal Mag- 
istra No. 82 Th. XXIV Desember 2012. Diakses dari http://journal.unwidha.ac.id/index.php/ magistra/article/viewFile/292/241

Sutiyono. (2012). Implementasi pembelajaran tematik di sekolah dasar. Diakses tanggal 7 Mei 2013 dari http://sutiyonokudus.wordpress. com/2012/12/27/implementasi-pembelajaran-tematik-di-sekolah-dasar-2/
Trianto. (2010). Mengembangkan model pembelajaran tematik. Jakarta : PT. Prestasi Pustakaraya - Jakarta. Wahyuni, V. (2013). Pembelajaran tematik dan penentuan KKM. Diakses dari http://www.slideshare. net/ZaenalKhayat/presentasikuviviwahyuni-130522071721phpapp02 tanggal 12 Pebruari 2014. 